\title{
KONSELING BAGI ANAK YANG MENGALAMI PERILAKU KEKERASAN
}

\author{
Hesty Nurrahmi \\ Fakultas Ushuluddin Adab dan Dakwah \\ Institut Agama Islam Negeri (IAIN) Pontianak \\ Email: es4ty@yahoo.com
}

\begin{abstract}
The violence behavior on children is often performed by the closest people of them, such as parents, family, and school environment. There are four categories of violence acts on children: negligence, physical assault, psychological and emotional harassment, and sexual harassment. This paper explores the counseling or the supporting towards the children experiencing the violence behaviors. Furthermore, those behaviors include the types of abuse acts, the causes of violence acts, and the counseling given to the children and family that encounter the violence behaviors.
\end{abstract}

\section{Keywords: Counseling, Children, Violence acts}

\section{PENDAHULUAN}

Anak merupakan dambaan setiap pasangan yang telah menikah. Bagi pasangan yang tidak bisa atau belum dikarunia anak, pasti akan sangat berharap hadirnya seorang anak dalam kehidupan mereka. Melalui berbagai cara dan usaha dilakukan untuk memperoleh anak. Berbeda dengan pasangan yang telah memiliki anak, berbagai cara memperlakukan anak, ada yang otoriter dengan alasan sangat menyanyangi anak-anak mereka, ada yang tipe otoritatif anak diperlakukan bebas, terbatas dan bertanggungjawab, ada lagi tipe yang selain kedua di atas yaitu tipe permisif. Tipe ini biasanya membiarkan anak-anak mereka mengatur hidup mereka sendiri, mungkin karena kesibukan orangtua atau tidak mengetahui cara mengasuh anak. Anak adalah amanah atau titipan Allah SWT kepada kita. Untuk itu diperlukan ilmu dan kesabaran dalam mengasuh, mendidik dan merawat anak.

Keluarga merupakan pendidikan pertama dan utama bagi anak (Mansur: 2005). Berawal dari keluarga, anak belajar berbagai hal. Namun, terkadang melalui keluarga dan orang-orang terdekat, anak memperoleh perilaku kekerasan. Kekerasan terhadap anak(menurut Wikipedia:2015) adalah tindak kekerasan secara fisik, seksual, penganiyaan emosional, atau pengabaian terhadap anak. Di Amerika Serikat, Pusat Pengendalian dan Pencegahan Penyakit (CDC) mendefinisikan penganiayaan anak sebagai setiap tindakan atau serangkaian tindakan wali atau kelalaian oleh orang tua atau pengasuh lainnya yang dihasilkan dapat membahayakan, atau berpotensi bahaya, atau memberikan ancaman yang berbahaya kepada anak. Sebagian besar terjadi kekerasan terhadap anak di rumah anak itu sendiri dengan jumlah yang lebih kecil terjadi di sekolah, di lingkungan atau organisasi tempat anak berinteraksi. Ada empat kategori utama tindak kekerasan terhadap anak yaitu: pengabaian, kekerasan fisik, pelecehan emosional/psikologis, dan pelecehan seksual anak.Beberapa kasus yang memiliki kategori kekerasanpada anak antara lain: kasus yang dialami DA (10) anak yang disetrika oleh ibu tirinya berinisial S (33) hingga mengakibatkan luka melepuh di bagian pipi. (23 Maret 2015); Komisi Perlindungan Anak Indonesia (KPAI) menganggap kalau sekolah kini bukan tempat yang aman bagi anak. Sekolah yang seharusnya memberikan perlindungan dan pengetahuan berganti menjadi tempat yang menakutkan bagi anak."Fenomena punishment bermuatan kekerasan masih terjadi. Masa orientasi 
siswa baru belum steril dari kekerasan," kata Susanto komisioner KPAI bidang pendidikan kepada wartawan. Masalah bullying, lanjut Susanto masih jadi tradisi dibeberapa sekolah. Perbuatan senior yang melakukan penindasan kepada junior dianggap biasa. "Ini diabaikan oleh sekolah. Seolah ada pembenaran terkait muatan kekerasan itu," tambahnya. Titik-titik rawan kejahatan seksual, lanjut Susanto di sekolah antara lain laboratorium komputer, toilet, lokasi sekolah yang tak terekam oleh CCTV, kolam renang. "Jadi tetap harus berhati-hati saat berada di sekolah. Bagi sekolah harus selalu evaluasi sejauh mana bisa bertindak tanpa kekerasan dalam proses belajar mengajar," tutup Susanto. (Metro sindonws: 2015)

Selain itu, pengaduan tindak kriminal anak dan perempuan Kota Depok meningkat dibanding tahun lalu. Pada tahun 2014 tercatat ada 113 kasus, tahun ini bertambah menjadi 204 kasus. Anggota Komisi D DPRD Kota Depok Rezky M. Noor mengaku miris dengan meningkatnya kasus kekerasan anak dan perempuan. Peningkatan tersebut dipicu pula oleh tingginya kesadaran masyarakat untuk melapor ketika menjadi korban kekerasan. "Adanya peningkatan laporan kasus ini kami rasa bukan karena tindakan kriminal melainkan karena para korban dan warga berani melaporkan kejadian kepada pihak kepolisian," kata Rezky usai pertemuan dengan pihak kepolisian Unit Pelayanan Perempuan dan Anak di Polresta Kota Depok. (Metro Sindonews:2015)

Data pengaduan kejahatan terhadap anak yang diterima oleh Polresta Depok kekerasan terhadap anak mencapai 36 kasus, persetubuhan terhadap anak 40 kasus, pencabulan terhadap anak 32 kasus. "Dari temu wicara kami dengan aparat Kepolisian setiap harinya mendapatkan sekitar 15 kasus kekerasan terhadap anak dan perempuan," katanya. Sebelumnya, seorang anak tunarungu menjadi korban perkosaan tetangganya sendiri. DR, siswi kelas V sebuah SLB di Depok diduga diperkosa ketika pulang sekolah. Saat itu korban baru saja turun dari jemputan dan jalan kaki menuju rumahnya seorang diri. Korban kemudian ditarik pelaku ke lahan kosong dan diduga disetubuhi.

Demikianlah beberapa kasus perilaku kekerasan pada anak yang secara kuantitas tiap tahun menunjukkan peningkatan dan secara kualitas menunjukkan kekerasan yang parah dan memberikan luka yang mendalam baik secara fisik maupun psikis. Masalah ini tidak dapat dipungkiri akan berdampak yang luar biasa bagi anak baik dimasa sekarang maupun masa akan datang. Tulisan selanjutnya akan menguraikan jenis-jenis perilaku kekerasan, penyebab perilaku kekerasan dan bantuan konseling yang dapat diberikan bagi anak dan keluarga yang mengalami perilaku kekerasan.

\section{JENIS PERILAKU KEKERASAN}

Beberapa penelitian, perilaku kekerasan dapat dirumuskan dalam bentuk pengabaian, penyiksaan fisik, penyiksaan emosi dan pelecehan seksual.

1. Pengabaian, contoh kasus: Vira (24 th), punya anak tak lama setelah menikah. Ia merasa menjadi tawaan yang tidak bebas lagi berkumpul dengan teman-teman. "Real life tak seperti romantisme yang saya bayangkan. Kebebasan saya terampas," ujarnya. Maka pengasuhan bayi sepenuhnya diserahkan pada baby-sitter. Vira sendiri selalu pulang tepat sebelum suaminya tiba di rumah, seolah seharian mengurus anak. Padahal, "Tidur, mandi, makan, susu, bahkan uang belanja harian dan bulanan, saya serahkan sepenuhnya pada baby-sitter. Saya tak mau tertawan." 
Pengabaian bermakna membiarkan anak tanpa memberikan pengasuhan, penjagaan dan perhatian secara baik dan benar. Pengabaian terhadap anak termasuk penyiksaan secara pasif, yaitu segala ketiadaan perhatian yang memadai, baik fisik, emosi maupun sosial. Pengabaian anak banyak dilaporkan sebagai kasus terbesar dalam kasus penganiayaan terhadap anak dalam keluarga. Dampak fisik yang dapat dirasakan anak seperti kurangnya asupan gizi, tidak terurusnya anak dalam segi kebersihan pakaian, dan kebersihan badan. Sedangkan dampak emosi seperti mudah cemas, depresi, sulit percaya pada orang lain dan merasa tidak aman; penelitian Dante Cicchetti, ahli psikopatologi dari University of Minessota (AS) menyebut, $80 \%$ bayi yang ditelantarkan menunjukkan perilaku kelekatan yang tidak jelas; di usia muda anak menolak dan melawan pengasuhnya, bingung, gelisah, atau cemas. Di usia 6 tahun, anak tidak bertingkah laku layaknya anak, ia ingin mendapat perhatian dengan cara melayani orangtuanya. Secara rinci jenis-jenis pengabaian anak:

a. Pengabaian fisik, misalnya keterlambatan mencari bantuan medis, pengawasan yang kurang memadai, serta tidak tersedianya kebutuhan akan rasa aman dalam keluarga.

b. Pengabaian pendidikan terjadi ketika anak seakan-akan mendapat pendidikan yang sesuai padahal anak tidak dapat berprestasi secara optimal. Lama kelamaan hal ini dapat mengakibatkan prestasi sekolah yang semakin menurun.

c. Pengabaian secara emosi dapat terjadi misalnya ketika orangtua tidak menyadari kehadiran anak ketika 'ribut' dengan pasangannya. Atau orangtua memberikan perlakuan dan kasih sayang yang berbeda diantara anak-anaknya.

d. Pengabaian fasilitas medis. Hal ini terjadi ketika orangtua gagal menyediakan layanan medis untuk anak meskipun secara finansial memadai. Dalam beberapa kasus orangtua memberi pengobatan tradisional terlebih dahulu, jika belum sembuh barulah kembali ke layanan dokter.

\section{Efek Pengabaian Anak}

Pengaruh yang paling terlihat adalah kurangnya perhatian dan kasih sayang orangtua terhadap anak. Bayi yang dipisahkan dari orangtuanya dan tidak memperoleh pengganti pengasuh yang memadai, akan mengembangkan perasaan tidak aman, gagal mengembangkan perilaku akrab (Hurlock, 1990), dan selanjutnya akan mengalami masalah penyesuaian diri pada masa yang akan datang. Faktor-faktor lain yang menjadi dialami anak:

a. Faktor usia anak. Semakin muda usia anak maka akan menimbulkan akibat yang lebih fatal.

b. Siapa yang terlibat. Jika yang melakukan penganiayaan adalah orang tua, ayah atau ibu tiri, atau anggota keluarga maka dampaknya akan lebih parah daripada yang melakukannya orang yang tidak dikenal.

c. Seberapa parah. Semakin sering dan semakin buruk perlakuan yang diterima anak akan memperburuk kondisi anak.

d. Berapa lama terjadi. Semakin lama kejadian berlangsung akan semakin meninggalkan trauma yang membekas pada diri anak.

e. Jika anak mengungkapkan penganiayaan yang dialaminya, dan menerima dukungan dari orang lain atau anggota keluarga yang dapat mencintai, mengasihi dan memperhatikannya maka kejadiannya tidak menjadi lebih parah sebagaimana jika anak justru tidak dipercaya atau disalahkan. 
f. Tingkatan sosial ekonomi. Anak pada keluarga dengan status sosial ekonomi rendah cenderung lebih merasakan dampak negatif dari penganiayaan anak.

2. Penyiksaan Fisik, Segala bentuk penyiksaan fisik terjadi ketika orangtua frustrasi atau marah, kemudian melakukan tindakan-tindakan agresif secara fisik, dapat berupa cubitan, pukulan, tendangan, menyulut dengan rokok, membakar, dan tindakan-tindakan lain yang dapat membahayakan anak. Sangat sulit dibayangkan bagaimana orangtua dapat melukai anaknya. Sering kali penyiksaan fisik adalah hasil dari hukuman fisik yang bertujuan menegakkan disiplin, yang tidak sesuai dengan usia anak. Banyak orangtua ingin menjadi orangtua yang baik, tapi lepas kendali dalam mengatasi perilaku sang anak. Efek dari penyiksaan fisik:Penyiksaan yang berlangsung berulang-ulang dalam jangka waktu lama akan menimbulkan cedera serius terhadap anak, dan meninggalkan bekas baik fisik maupun psikis, anak menjadi menarik diri, merasa tidak aman, sukar mengembangkan trust kepada orang lain, perilaku merusak, dan lain-lain. Dan bila kejadian berulang ini terjadi maka proses recoverynya membutuhkan waktu yang lebih lama pula.

3. Penyiksaan Emosi, adalah semua tindakan merendahkan atau meremehkan orang lain. Jika hal ini menjadi pola perilaku maka akan mengganggu proses perkembangan anak selanjutnya. Hal ini dikarenakan konsep diri anak terganggu, selanjutnya anak merasa tidak berharga untuk dicintai dan dikasihi. Anak yang terus menerus dipermalukan, dihina, diancam atau ditolak akan menimbulkan penderitaan yang tidak kalah hebatnya dari penderitaan fisik. Bayi yang menderita deprivasi (kekurangan) kebutuhan dasar emosional, meskipun secara fisik terpelihara dengan baik, biasanya tidak bisa bertahan hidup. Deprivasi emosional tahap awal akan menjadikan bayi tumbuh dalam kecemasan dan rasa tidak aman, dimana bayi lambat perkembangannya, atau akhirnya mempunyai rasa percaya diri yang rendah.

Jenis-jenis penyiksaan emosi adalah:

a. Penolakan, Orangtua mengatakan kepada anak bahwa dia tidak diinginkan, mengusir anak, atau memanggil anak dengan sebutan yang kurang menyenangkan. Kadang anak menjadi kambing hitam segala problem yang ada dalam keluarga.

b. Tidak diperhatikan, Orangtua yang mempunyai masalah emosional biasanya tidak dapat merespon kebutuhan anak-anak mereka. Orangtua jenis ini mengalami problem kelekatan dengan anak. Mereka menunjukkan sikap tidak tertarik pada anak, sukar memberi kasih sayang, atau bahkan tidak menyadari akan kehadiran anaknya. Banyak orangtua yang secara fisik selalu ada disamping anak, tetapi secara emosi sama sekali tidak memenuhi kebutuhan emosional anak.

c. Ancaman, Orangtua mengkritik, menghukum atau bahkan mengancam anak. Dalam jangka panjang keadaan ini mengakibatkan anak terlambat perkembangannya, atau bahkan terancam kematian.

d. Isolasi, Bentuknya dapat berupa orangtua tidak mengijinkan anak mengikuti kegiatan bersama teman sebayanya, atau bayi dibiarkan dalam kamarnya sehingga kurang mendapat stimulasi dari lingkungan, anak dikurung atau dilarang makan sesuatu sampai waktu tertentu.

e. Pembiaran, Membiarkan anak terlibat penyalahgunaan obat dan alkohol, berlaku kejam terhadap binatang, melihat tayangan porno, atau terlibat dalam tindak kejahatan seperti mencuri, berjudi, berbohong, dan sebagainya. Untuk anak yang lebih kecil, 
membiarkannya menonton adegan-adegan kekerasan dan tidak masuk akal di televisi termasuk juga dalam kategori penyiksaan emosi.

\section{Efek dari Penyiksaan Emosi}

Penyiksaan emosi sukar diidentifikasi atau didiagnosa karena tidak meninggalkan bekas yang nyata seperti penyiksaan fisik. Dengan begitu, usaha untuk menghentikannya juga tidak mudah. Jenis penyiksaan ini meninggalkan bekas yang tersembunyi yang termanifestasikan dalam beberapa bentuk, seperti kurangnya rasa percaya diri, kesulitan membina persahabatan, perilaku merusak seperti tiba-tiba membakar barang atau bertindak kejam terhadap binatang, beberapa melakukan agresi, menarik diri, penyalahgunaan obat dan alkohol, ataupun kecenderungan bunuh diri.

4. Pelecehan seksual, Sampai saat ini tidaklah mudah membicarakan hal ini, atau untuk menyadarkan masyarakat bahwa pelecehan seksual pada setiap usia - termasuk bayi mempunyai angka yang sangat tinggi. Bahkan Hopper (2004) mengemukakan bahwa hal ini terjadi setiap hari di Amerika Serikat.Pelecehan seksual pada anak adalah kondisi dimana anak terlibat dalam aktivitas seksual dimana anak sama sekali tidak menyadari, dan tidak mampu mengkomunikasikannya, atau bahkan tidak tahu arti tindakan yang diterimanya.Semua tindakan yang melibatkan anak dalam kesenangan seksual masuk dalam kategori ini:

a. Pelecehan seksual tanpa sentuhan. Termasuk di dalamnya jika anak melihat pornografi, atau exbibitionisme, dsb.

b. Pelecehan seksual dengan sentuhan. Semua tindakan anak menyentuh organ seksual orang dewasa termasuk dalam kategori ini. Atau adanya penetrasi ke dalam vagina atau anak dengan benda apapun yang tidak mempunyai tujuan medis.

c. Eksploitasi seksual. Meliputi semua tindakan yang menyebabkan anak masuk dalam tujuan prostitusi, atau menggunakan anak sebagai model foto atau film porno.

Ada beberapa indikasi yang patut kita perhatikan berkaitan dengan pelecehan seksual yang mungkin menimpa anak seperti keluhan sakit atau gatal pada vagina anak, kesulitan duduk atau berjalan, atau menunjukkan gejala kelainan seksual.

\section{Efek Pelecehan Seksual}

Banyak sekali pengaruh buruk yang ditimbulkan dari pelecehan seksual. Pada anak yang masih kecil dari yang biasanya tidak mengompol jadi mengompol, mudah merasa takut, perubahan pola tidur, kecemasan tidak beralasan, atau bahkan simtom fisik seperti sakit perut atau adanya masalah kulit, dan lain-lain. Pada remaja, mungkin secara tidak diduga menyulut api, mencuri, melarikan diri dari rumah, mandi terus menerus, menarik diri dan menjadi pasif, menjadi agresif dengan teman kelompoknya, prestasi belajar menurun, terlibat kejahatan, penyalahgunaan obat atau alkohol, dan sebagainya.

\section{PENYEBAB PERILAKU KEKERASAN}

Faktor-faktor yang menyebabkan perilaku kekerasan terhadap anak antara lain immaturitas/ketidakmatangan orangtua, kurangnya pengetahuan bagaimana menjadi orangtua, harapan yang tidak realistis terhadap kemampuan dan perilaku anak, pengalaman negatif masa kecil dari orangtua, isolasi sosial, problem rumah tangga, serta problem obat-obat terlarang dan alkohol. Ada juga orangtua yang tidak menyukai peran sebagai orangtua sehingga terlibat 
pertentangan dengan pasangan dan tanpa menyadari bayi/anak menjadi sasaran amarah dan kebencian.

Menurut Gelles Richard J. (1982) mengemukakan bahwa kekerasan terhadap anak (child abuse) terjadi akibat kombinasi dari berbagai faktor, yaitu:

a. Pewarisan Kekerasan Antar Generasi (intergenerational transmission of violence).

Banyak anak belajar perilaku kekerasan dari oran tuanya dan ketika tumbuh menjadi dewasa mereka melakuakan tindakan kekerasan kepada anaknya. Dengan demikian, perilaku kekerasan diwarisi (transmitted) dari generasi ke generasi. Studi studi menunjukkan bahwa lebih kurang 30\% anak-anak yang diperlakukan dengan kekerasan menjadi orangtua yang bertindak keras kepada anak anaknya.

Sementara itu, hanya 2 sampai 3 persen dari semua individu menjadi orangtua yang memperlakukan kekerasan kepada anak-anaknya. Anak-anak yang mengalami perlakuan salah dan kekerasan mungkin menerima perilaku ini sebagai model perilaku mereka sendiri sebagai orang tua. Tetapi, sebagian besar anak-anak yang diperlakukan dengan kekerasan tidak menjadi orang dewasa yang memperlakukan kekerasan kepada anak-anaknya.

b. Stres Sosial (social stress)

Stres yang ditimbulkan oleh berbagai kondisi sosial meningkatkan risiko kekerasan terhadap anak dalam keluarga. Kondisi-kondisi sosial ini mencakup: pengangguran (unemployment), penyakit (illness), kondisi perumahan buruk (poor housing conditions), ukuran keluarga besar dari rata-rata (a larger than average family size), kelahiran bayi baru (the presence of a new baby), orang cacat (disabled person) di rumah, dan kematian (the death) seorang anggota keluarga. Sebagian besar kasus dilaporkan tentang tindakan kekerasan terhadap anak berasal dari keluarga yang hidup dalam kemiskinan.

Tindakan kekerasan terhadap anak juga terjadi dalam keluarga kelas menengah dan kaya, tetapi tindakan yang dilaporkan lebih banyak di antara keluarga miskin karena beberapa alasan.

c. Isolasi Sosial dan Keterlibatan Masyarakat Bawah

Orangtua dan pengganti orangtua yang melakukan tindakan kekerasan terhadap anak cenderung terisolasi secara sosial. Sedikit sekali orangtua yang bertindak keras ikut serta dalam suatu organisasi masyarakat dan kebanyakan mempunyai hubungan yang sedikit dengan teman atau kerabat.

d. Struktur Keluarga

Tipe-tipe keluarga tertentu memiliki risiko yang meningkat untuk melakukan tindakan kekerasan dan pengabaian kepada anak. Misalnya, orang tua tunggal lebih memungkinkan melakukan tindakan kekerasan terhadap anak dibandingkan dengan orangtua utuh. Selain itu, keluarga keluarga di mana baik suami atau istri mendominasi di dalam membuat keputusan penting, seperti : di mana bertempat tinggal, pekerjaan apa yang mau diambil, bilamana mempunyai anak, dan beberapa keputusan lainnya, mempunyai tingkat kekerasan terhadap anak yang lebih tinggi dibandingkan dengan keluarga keluarga yang suami istri sama sama bertanggungjawab atas keputusan keputusan tersebut.

\section{BANTUAN KONSELING BAGI ANAK YANG MENGALAMI PERILAKU KEKERASAN}

1. Periksa anak ke dokter/psikolog/psikiater untuk mengetahui tumbuh-kembangnya serta status gizinya. 
2. Penuhi kebutuhan anak untuk menumbuhkan rasa percaya dan rasa aman.

3. Ajak anak bermain dan penuhi kebutuhan emosinya seperti diajak bicara atau dibelai, namun tetap mempertahankan sikap konsisten, tidak cepat marah dan tidak memberi penilaian negatif pada sikap anak.

4. Untuk kasus tertentu, perlu penanganan mendalam, misalnya anak yang mengalami trauma fisik dan psikis. Berbagai terapi atau treatment yang dapat digunakan sesuai perilaku kekerasan yang di alami anak.

5. Untuk kasus pengabaian anak dan penyiksaan emosi, konseling yang diberikan antara lain memberikan perhatian dan kasih sayang yang ekstra, memperbaiki komunikasi orangtua-anak. Untuk kasus ini peran orang tua sangat penting. Konselor atau terapis hanya bersifat mengarahkan.

6. Untuk kasus penyiksaan fisik dan pelecehan seksual, konseling yang diberikan perlu beberapa kali konseling atau treatment, tergantung tingkat keparahan yang dialami anak. Bagi anak-anak teknik konseling yang dapat digunakan, dapat berupa terapi bermain, menggambar atau bercerita tergantung identifikasi kasus dan kebutuhan anak. Metode yang dapat digunakan dapat melalui konseling kelompok maupun individual.

7. Tujuan dari teknik yang digunakan: membantu anak mengembangkan kekuatan yang berpusat dan mengaktualisasikan diri mereka sehingga mereka dapat menghadapi dengan lebih sukses dengan diri mereka dan lingkungannya.

Contoh kasus, dengan bantuan konseling individual:

Latar belakang informasi. St umur 10 tahun, anak tengah dari 5 bersaudara, memiliki 2 saudara perempuan dan 2 saudara laki-laki. Kedua orang tuanya sibuk bekerja dan aktif dalam kegiatan masyarakat. Ibu St mempunyai sifat yang otoriter dan disiplin yang percaya bahwa orangtua harus "keras" dengan anak-anaknya. Orangtua St mengalami kesulitan berhubungan dengan anak-anak mereka dan memilih untuk memperlakukan mereka sebagai miniature orang dewasa. Semua anak mengalami masalah dalam hubungan pribadi. Anak yang besar mempunyai masalah emosi dan sedang dalam proses penyembuhan.

Penyampaian masalah. St dikirim ke konseling karena dia berjalan kaku, gerak tubuh dan bicaranya seperti robot, dan mengatakan bahwa teman sekelasnya adalah anak-anak dari luar angkasa. Tingkahlakunya menjadikan St menjadi bahan tertawaan teman-teman sebayanya. St sangat pendiam dan mengasingkan diri, dan menurut hasil sosiogram dia tidak mempunyai teman dalam kelasnya. Gurunya hari ini menyampaikan: Hari ini St bersembunyi di belakang selama 40 menit meskipun dia harus ke kelas matematika. Tidak ada penjelasan-hanya menangis.

Pertemuan ke I (Awal): Mengembangkan Hubungan

Pertemuan awal dengan St. Selama awal pertemuan St tampak rapuh, nervous, dan sangat pucat. Dia berbicara seperti robot untuk menunjukkan hidupnya secara detail pada planet lain. St menyampaikan dia telah bermimpi dan dia menulis kepada orang-orang planet dan akan mengirimnya kepada konselor. St diminta untuk menggambar. St menggambar sebuah keluarga dengan wajah robot dengan wajah kaku, satu sama lain tidak berinteraksi. Dia menggambar seorang tukang sihir dengan wajah yang buruk yang dia identifikasikan sebagai (Jn) anak tertua.

Konselor menggunakan pertemuan pertama dengan memulai hubungan kerjasama dengan orangtua anak. Ditambah dengan membentuk rapportdan mengembangkan hubungan kerjasama 
dengan anak, pertemuan awal konselor memberikan kesempatan kepada orangtua untuk mengungkapkan masalah mereka dan mereka merasa dihargai dan dimengerti. Pada pertemuan awal ini, konselor mendapatkan informasi tentang gaya hidup orangtua dan interaksi orangtua dan anak. Dalam mengeksplorasi hubungan orangtua anak, konselor menemukan sebagian besar gangguan hubungan antara orang tua dan anak.

Pertemuan ke 2 dan seterusnya dilakukan konselor sebagai proses konseling yang terdiri, pengungkapan masalah dari anak dan keluarga, melakukan proses treatment, penyadaran diri anak, aktualisasi diri dan sampai akhirnya St perlahan-lahan mengubah perilakunya yang kaku seperti robot. Dia berhenti sakit dan sering menangis. Akhirnya, dia diterima oleh anak-anak teman sebayanya dalam kelas dan mereka mulai bermain catur bersama-sama. Pada puncak kesembuhannya, St menemukan bahwa lebih nyaman menjadi anak laki-laki daripada tetap menjadi makhluk planet/robot.

\section{PENUTUP}

Demikianlah uraian tentang konseling terhadap perilaku kekersan pada anak dan salah satu contoh kasus anak dengan perilaku keras atau sikap otoriter orangtua. Melalui proses konseling yang berkali-kali dan cukup lama, serta peran serta orangtua dan keluarga, anak dapat mengalami perubahan dan penyembuhan. Namun kesembuhan anak yang terjadi tidak berarti anak sehat 100\%, akan tetapi harus terus dibarengi dengan mengkondisikan hubungan dan lingkungan yang sehat, tetap memberikan perhatian dan kasih sayang yang optimal. ${ }^{*}$ )

\section{REFERENSI}

Elizabeth Hurlock (1990), Child Development. Sixth Edition. New York: Mc Graw Hill, Inc.

Sri Esti W.D (2005) Konseling dan Terapi dengan Anak dan Orangtua, Jakarta: Grasindo.

Mansur, (2005). Pendidikan Anak Usia Dini dalam Islam. Yogyakarta: Pustaka Pelajar.

http://www.ayahbunda.co.id/Artikel/balita/psikologi/contoh.kasus.kekerasan.terhadap.anak.da n.dampaknya/001/007/430/1/1 1 april 2015

http://www.smallcrab.com/anak-anak/550-beberapa-jenis-kekerasan-pada-anak 1 april 2015

http://metro.sindonews.com/read/980860/170/bocah-10-tahun-disetrika-ahok-ibu-tiri-lebihkejam-dari-ibu-kota-1427199973 24 maret 2015 di ambil 1 april 2015

http://metro.sindonews.com/read/936149/31/kasus-kekerasan-anak-di-depok-meningkat1418307744

http://yosephineyohana.blogspot.com/2013/09/penyebab-kekerasan-terhadap-anak-pi-gw.html

http://id.wikipedia.org/wiki/Kekerasan_terhadap_anak 